\title{
Anaerobic Digestion of Parthenium Weed with Goat Manure to Generate Biogas Energy
}

\author{
Getu Hailu ${ }^{1, *}$, Meseret Chimdessa ${ }^{2}$ \\ ${ }^{1}$ Department of Biotechnology, College of Natural and Computational Sciences, Wolkite University, Wolkite, Ethiopia \\ ${ }^{2}$ Departement of Biology, College of Natural and Computational Science, Haramaya University, Haramaya, Ethiopia
}

Email address:

abelbrukgetu@gmail.com(G. Hailu)

${ }^{*}$ Corresponding author

To cite this article:

Getu Hailu, Meseret Chimdessa. Anaerobic Digestion of Parthenium Weed with Goat Manure to Generate Biogas Energy. International Journal of Energy and Power Engineering. Vol. 9, No. 3, 2020, pp. 35-40. doi: 10.11648/j.ijepe.20200903.12

Received: June 3, 2020; Accepted: June 19, 2020; Published: July 30, 2020

\begin{abstract}
The aim of this study was to obtain the optimal Mix ratio for biogas production from anaerobic digestion of Parthenium weed and goat manure. The experiment was batch operated and daily gas yield from the plant was monitored for 30 days. The Parameters studied were total solids (TS) and volatile solids (VS), fixed solids, organic carbon, and moisture content. For the experimental design, different mix ratios were adopted for the five digesters employed. In this case, for the first digester, $100 \%$ goat manure was used. For the $2^{\text {nd }}$ digester $75 \% \mathrm{GM}$ and $25 \% \mathrm{PW}$ were used. The $3^{\text {rd }}$ digester was filled with GM and PW in 1:1 ratio. The $4^{\text {th }}$ digester contained $25 \% \mathrm{GM}$ and $75 \% \mathrm{PW}$. the last digester contained only PW. The gas production rate was measured on daily basis using water displacement method. Gas production was noticed in all of the substrates types from the second and third day of digestion and went to zero at about 28 days in all digesters. The experimental data shows a greatest gas output of $572.5 \mathrm{ml}$ of gas production in the mix ratio of $75 \% \mathrm{GM}$ and $25 \% \mathrm{PW}$, suggesting this mix ratio of the two substrates is an optimal mix to yield the highest biogas production. All measured TS, VS, PH, organic carbon and moisture content were significantly varied between before and after AD. Overall results indicates that the biogas yield and VS and TS reduction can be significantly enhanced when GM and PW are co digested.
\end{abstract}

Keywords: Biogas, Co-digestion, Goat Manure, Parthenium Weed, Total Solid, Volatile Solid

\section{Introduction}

Fossil fuels are the main contributor to the emission of greenhouse gases causing climate change and unprecedented environmental problems. The impact of climate change is projected to increase rapidly because of continued dominance of the use of fossil fuels in many countries [1]. In addition, many households in the developing world today burn biomass in traditional stoves to obtain heat. This burning can result in indoor pollution and human health problems [2].

The anaerobic digestion of biomass requires less capital investment per unit production cost compared to other renewable energy sources, such as hydro, solar and wind energy [3]. Apart from this, the effluent from the biogas process supplies nutrients which can also be utilized as fertilizer [4]. Cattle dung has been used as the major feed material for anaerobic digesters which is not likely to have significant impact. This calls for widening the scope of this technology by tapping other organic materials like energy crops. Using spineless cacti as an energy crop is offering serious perspectives to countries prone to drought and relying on imports for their energy consumption [5].

Anaerobic digestion is a multi-stage biochemical process in which the complex organic materials undergo hydrolysis, acidogenesis, and methanogenesis in series and each metabolic stage is functioned by different types of microorganisms. Parthenium hysterophorus grows abundantly throughout Ethiopia. It is considered to be 
important energy plant for biogas production because of its high organic matter yield per hectare and high availability to supplement goat manure for biogas production [6].

Co-digestion of different plant and animal materials could be beneficial due to dilution of inhibitive substances, improved nutrient content (ammonium nitrogen, potassium, phosphorus, calcium, magnesium), synergistic effect between the treated materials resulting in better degradation of both and greater balance between carbon and nitrogen [7].

Objectives of the study

To evaluate the potential of Parthenium hysterophorus to produce biogas through anaerobic digestion alone or in combination with Goat manure.

To characterize Goat manure and Parthenium hysterophorus in terms of total solids (TS) and volatile solids (VS), fixed solids, organic carbon, and moisture content.

To find out the optimal Parthenium hysterophorus and goat manure mix ratio for high biogas production.

\section{Materials and Methods}

\subsection{Description of the Study Area}

The experiment was conducted in Microbiology laboratory Department of Biology at Haramaya University which is located at latitude of $9^{\circ} 26 \mathrm{~N}$, longitude of $42^{\circ} 03 \mathrm{E}$ and altitude of 1980 m.a.s.l. (FAO, 1990) The mean annual temperature is $17^{\circ} \mathrm{C}$ with mean minimum and maximum temperatures of 3.8 and $25^{\circ} \mathrm{C}$, respectively.

\subsection{Sample Collection}

Samples were collected (Parthenium weed) from Haramaya University compound. The fresh goat manure was obtained from goat farm in Haramaya University. The rumen fluid that will be used as inoculums was obtained from slaughter house of Haramaya University and stored at $5^{\circ} \mathrm{C}$. Parthenium weed was cut manually into small pieces and used for digestion.

\subsection{Design of the Experiment}

Anaerobic digestion was conducted in batch mode in $0.5 \mathrm{~L}$ digester using the two substrates, i.e., goat manure (GM) and Parthenium weed (PW) in five proportions to have five substrate treatments. The five substrate treatments were 100\% GM, 75\%: 25\% mix of GM: PW, 50\%:50\% mix of GM: PW, 25\%: $75 \%$ mix of GM: PW and $100 \% \mathrm{PW}$. To have $8 \%$ TS in fermenting slurry, appropriate amount of distilled water and rumen fluid $(100 \mathrm{ml})$ was mixed [8].

Treatments were randomly arranged in the lab and done in three replicates. The temperature of bio-digester was maintained at $38^{\circ} \mathrm{C}$ by keeping in oven, which represents mesophilic condition [9]. The $\mathrm{pH}$ of the slurry is maintained within the $\mathrm{pH}$ range for optimal biogas production, i.e. aboutneutral [10].

Table 1. The proportion of different substrates added in the five digesters.

\begin{tabular}{|c|c|c|c|c|c|c|}
\hline Sample & TS of GM (g) & TS of PW (g) & $\begin{array}{l}\text { Amount of water } \\
(\mathrm{ml})\end{array}$ & $\begin{array}{l}\text { Amount of inoculum } \\
\text { added }(\mathrm{ml})\end{array}$ & $\begin{array}{l}\text { Fresh Goat } \\
\text { manure (g) }\end{array}$ & $\begin{array}{l}\text { Parthenium } \\
\text { Weed (g) }\end{array}$ \\
\hline $\mathrm{D}_{1(100 \% \mathrm{GM})}$ & 40 & 0 & 200 & 100 & 200 & 0 \\
\hline $\mathrm{D}_{2(75 \% \mathrm{GM} \text { and } 25 \% \mathrm{PW})}$ & 30 & 10 & 200 & 100 & 150 & 50 \\
\hline $\mathrm{D}_{3(50 \% \mathrm{GM} \text { and } 50 \% \mathrm{PW})}$ & 20 & 20 & 200 & 100 & 100 & 100 \\
\hline $\mathrm{D}_{4(25 \% \mathrm{GM} \text { and } 75 \% \mathrm{PW})}$ & 10 & 30 & 200 & 100 & 50 & 150 \\
\hline $\mathrm{D}_{5(100 \% \mathrm{PW})}$ & 0 & 40 & 200 & 100 & 0 & 100 \\
\hline
\end{tabular}

\subsection{Digester Configuration and Setup for Biogas Production}

The three plastic bottles of $0.5 \mathrm{ml}$ were arranged in order in such a way that the first bottle contain slurry, the middle contain acidified brine solution and the last in order was empty for collecting the brine solution that was expelled out from the second container. The acidified brine solution was prepared by dissolving $\mathrm{NaCl}$ in distilled water with few drops of sulphuric acid until a supersaturated solution is formed to prevent the dissolution of biogas in the water. All the three containers were interconnected with plastic tubes having a diameter of $1 \mathrm{~cm}$. The tube connecting the first bottle to the second was fitted just above the slurry in the first bottle to help gas collection. Thus, the biogas produced by fermentation of the slurry was driven from the first bottle to the second bottle that contains a brine solution so as to displace a volume of the brine solution equivalent to the volume of biogas produced. The lids of all digester were sealed tightly using super glue in order to control the entry of oxygen and loss of biogas.

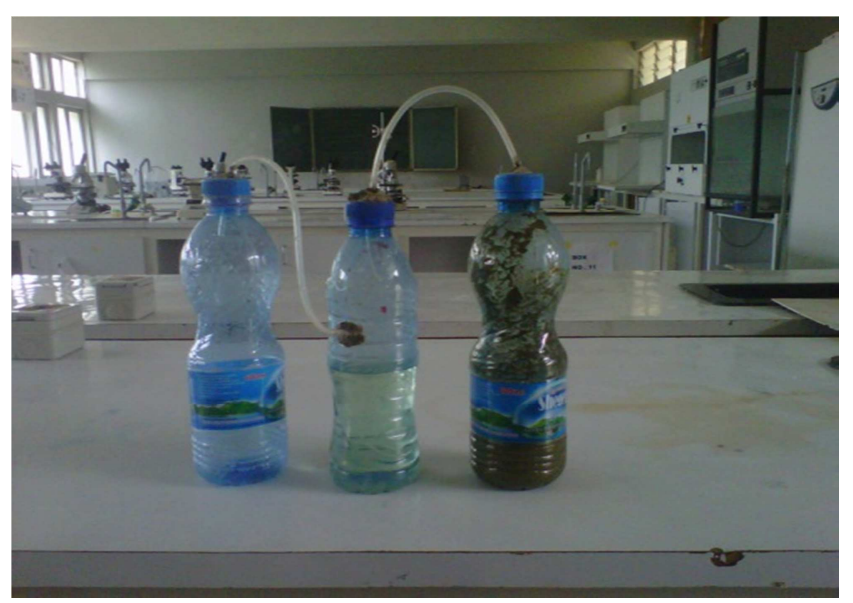

Figure 1. Arrangement of the digesters. 


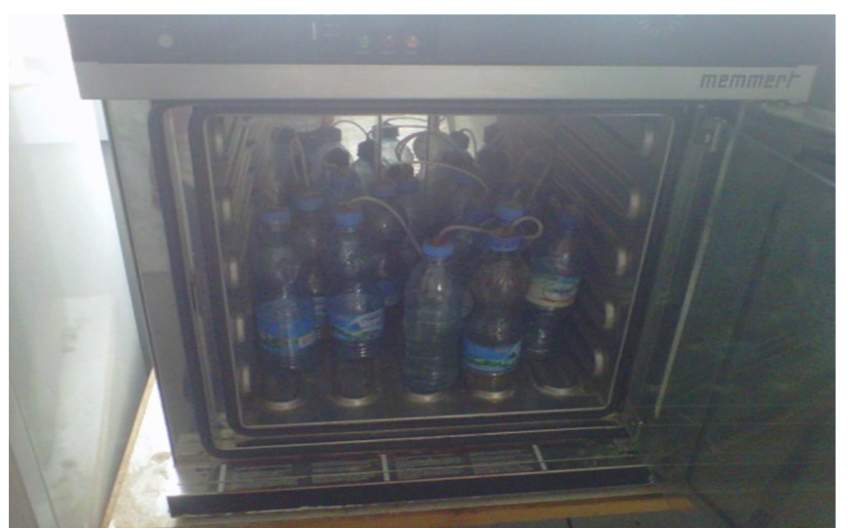

Figure 2. Digesters in the Oven.

\subsection{Data Analysis}

Data were first checked for their normality. Data that are not normally distributed were log-transformed and thereafter were subjected to the analysis of variance (one-way ANOVA) using SPSS 20.. Paired samples T-test was used to investigate statistical significance within a treatment. Difference between means was considered statistically significant at $P<0.05$.

\section{Results and Discussions}

In this observation, all the research analysis has been done under batch system. In the batch system, the slurry has been added once to the digester for whole duration of the process.

\subsection{Average Daily and Cumulative Biogas Production in Each Digester}

The quantity of biogas produced from the goat manure and Parthenium weed over a period of 30 days at an average temperature of $38^{\circ} \mathrm{C}$ are summarized in Figure 1. The total biogas from each treatment was measured until it stopped to produce any more gas. In the course of measurement, all substrate types appeared to yield more biogas than GM alone. This may be due to more availability of biodegradable material in PW than GM to serve as a source of energy for microbes. Thus, biogas production is a function of the feedstock's organic content and its biodegradability [11].

$\mathrm{T} 1=100 \% \mathrm{GM}$

$\mathrm{T} 2=75 \% \mathrm{GM}+25 \% \mathrm{PW}$

$\mathrm{T} 3=50 \% \mathrm{GM}+50 \% \mathrm{PW}$

$\mathrm{T} 4=25 \% \mathrm{GM}+75 \% \mathrm{PW}$

T5 $=100 \% \mathrm{PW}$

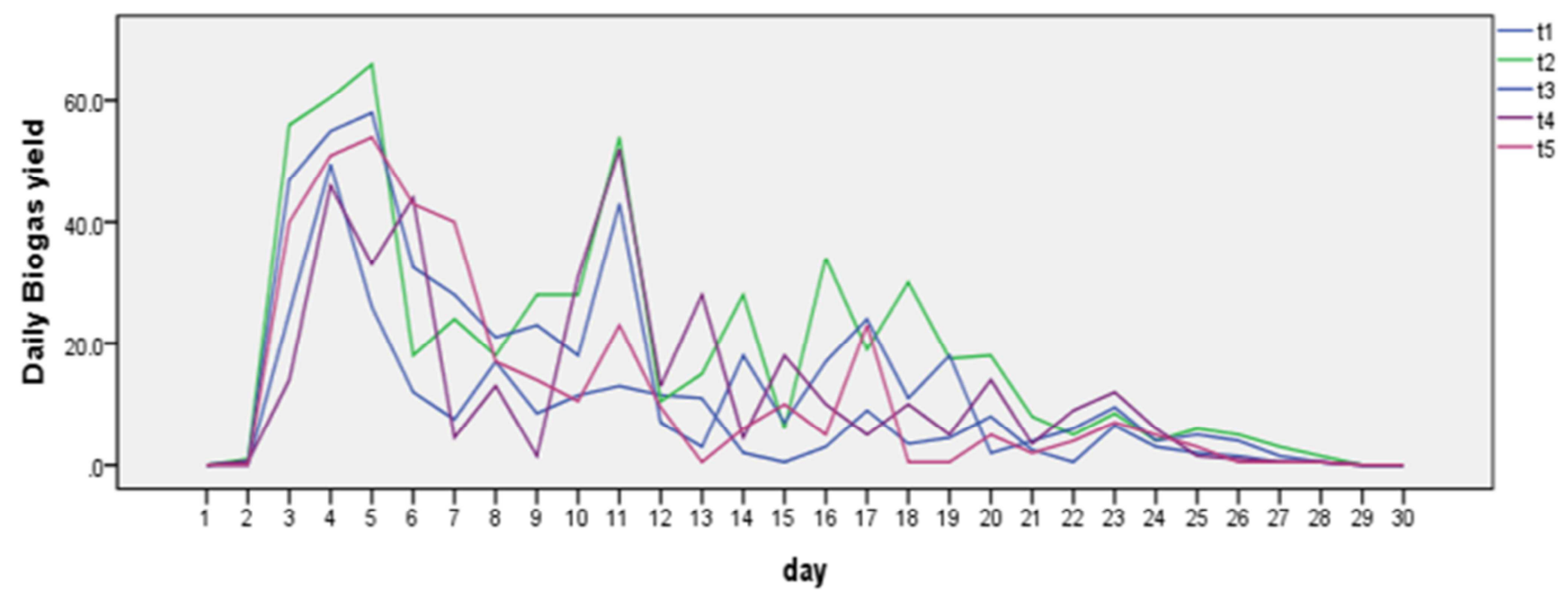

Figure 3. Daily mean Biogas yield of Parthenium weed and Goat manure in different mix ratios.

It was observed that biogas production was actually slow at end of the observation. This is predicted because biogas production rate in batch condition is directly equal to specific growth of methanogenic bacteria.

During the first day of observation, there was less biogas production mainly due to the lag phase of microbial growth. Whereas, in the range of 2-6 days of observation; biogas production increases substantially due to exponential growth of methanogens

It was observed that biogas production started in three digesters 2,3 and 4 on the $2^{\text {nd }}$ day after loading while production in digester 1 and 5 commenced on the $3^{\text {rd }}$ day. Highest biogas production occurred in the $2^{\text {nd }}$ digester with substrate mix of $75 \% \mathrm{GM}$ and $\mathrm{PW}$ and the lowest for $100 \% \mathrm{GM}$.

It was observed that biogas production was actually slow at starting and the end of observation. This is predicted because biogas production rate in batch condition is directly equal to specific growth of methanogenic bacteria [12].

During the first 3 days of observation, there was less biogas production and mainly due to the lag phase of microbial growth. Whereas, in the range of 4 to 6 days of observation; biogas production increases substantially due to exponential growth of methanogens.

The result obtained from the gas production showed that the $2^{\text {nd }}$ digester had the highest cumulative biogas yield of $572.5 \mathrm{ml} /$ total mass of slurry (TMS) while the $3^{\text {rd }}$ digester had $467.6 \mathrm{ml} /$ TMS followed by the $4^{\text {th }}$ and the $5^{\text {th }}$ digester with the yield of $376.1 \mathrm{ml}$ and $375 \mathrm{ml}$ respectively. The $1^{\text {st }}$ digester had with lowest cumulative biogas yield of $240 \mathrm{ml}$ /TMS within this retention period.

Production reached the peak on the $4^{\text {th }}$ day with only 
$49.5 \mathrm{ml}$ of gas produced in reactor 1 . digester 1 which contains $100 \%$ of goat manure alone resulted in less biogas probably due to its partial fermentation that usually takes place in digestive tract of the ruminant animal. [13]

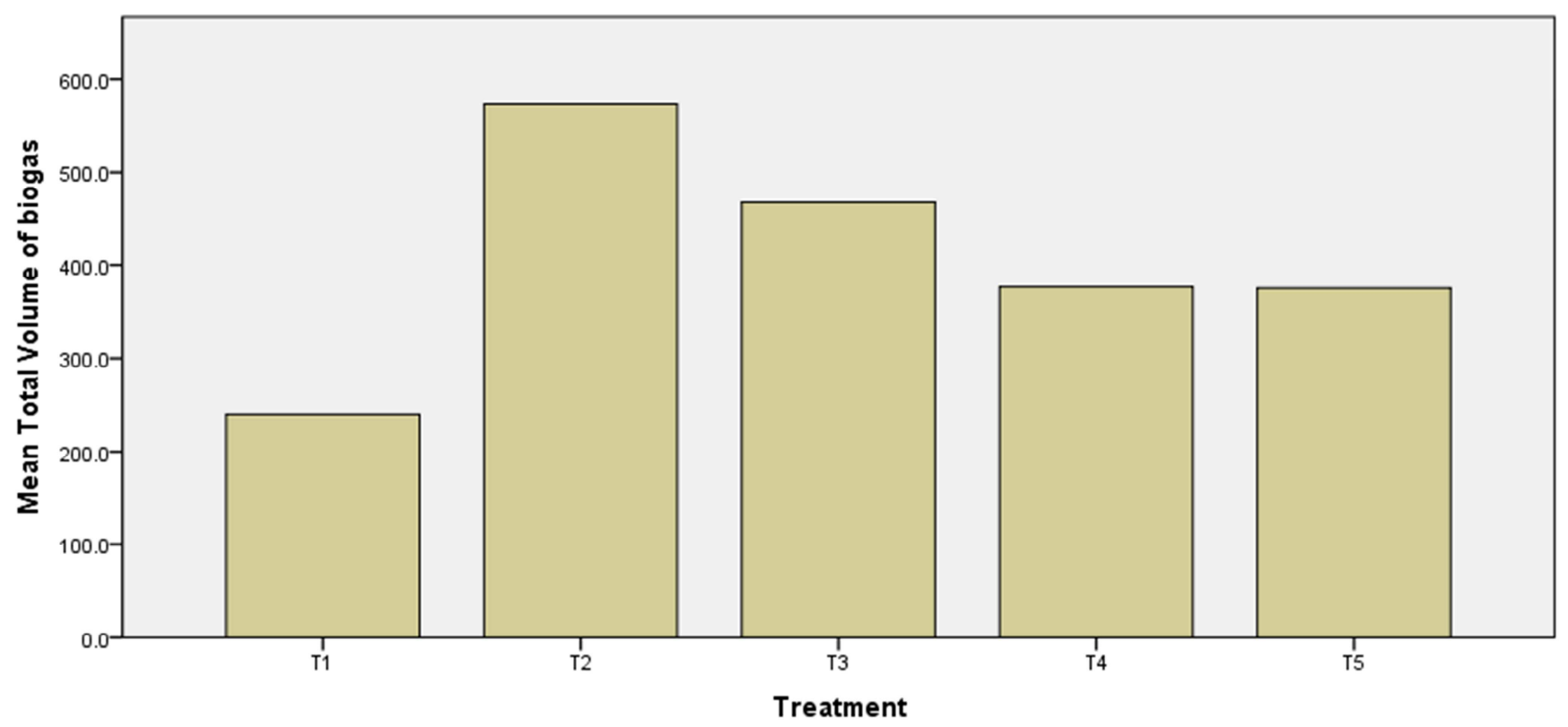

Figure 4. Mean total volume of biogas produced by different substrate concentration.

Digester 2 with $75 \% \mathrm{GM}$ and $25 \% \mathrm{PW}$ produced the highest cumulative biogas of $572.5 \mathrm{ml}$. There was a significant difference between the substrates in an overall biogas yield $(p<0.05)$. The highest cumulative production was produced in the system with the lowest concentration of plant material. This may be due to the high concentration of total nitrogen (ammonia) resulting from anaerobic breakdown of proteins to inhibit anaerobic digestion [14].

Thus it can be concluded that co-digestion of GM and PW is more productive with $\mathrm{PW}$ proportion not exceeding $25 \%$. The mixture produce the highest biogas may be due to a proper nutrient balance, increased buffering capacity, and decreased effect of toxic compounds resulting from mixing of the substrates [11].

Biogas production showed fluctuating decline after the first day of measurement and eventually reached $0 \mathrm{ml}$ on about $30^{\text {th }}$ day of the experiment (Figure 3 ). This might be due to the depletion of readily decomposable substrate after the first day [15]. and/or an increase in ammonium concentration that resulted in an increased $\mathrm{pH}$ values. It is also possible that accumulation of toxic wastes due to increasing microbial population in the digester might have inhibited gas production.

\subsection{Values of TS and VS and Other Physic Chemical Characterizations of the Feed Stocks}

Total solid and moisture content in the Goat manure and Parthenium weed were determined as follows. The substrate was transferred to a pre - weighed evaporating dish, and weighed altogether and recorded. It was then dried at $105^{\circ} \mathrm{C}$ in a drying oven for 24 hours. The dish with its contents was then cooled in a desiccator and weighed using an electronic weighing balance [16].

Table 2. Comparison of \%Organic carbon and Moisture content of GM and PW both before and after anaerobic digestion.

\begin{tabular}{lllll}
\hline Digester & \%Initial Carbon & \%Final carbon & \%Initial Moisture content & \%Final Moisture content \\
\hline $100 \% \mathrm{GM}$ & 8.6 & 7.7 & 75.5 & 81 \\
$75 \% \mathrm{GM}, 25 \% \mathrm{PW}$ & 8.8 & 7.2 & 78 & 83 \\
$50 \% \mathrm{GM}, 50 \% \mathrm{PW}$ & 10 & 7.5 & 80 & 82 \\
$25 \% \mathrm{GM}, 75 \% \mathrm{PW}$ & 10.5 & 7.8 & 77 & 81 \\
$100 \% \mathrm{PW}$ & 11.1 & 6.2 & 76 & 78 \\
\hline
\end{tabular}

The carbon content of the feed stock was obtained from volatile solids data $(\%$ carbon $=\% \mathrm{VS} / 1.8)$ as reported by Haug [17]. Before $\mathrm{AD}$, the mean moisture content for $100 \% \mathrm{GM}, 75 \% \mathrm{GM}$ and $25 \% \mathrm{PW}, 50 \% \mathrm{GM}$ and $50 \% \mathrm{PW}$,
$25 \% \mathrm{GM}$ and $75 \% \mathrm{PW}$ and $100 \% \mathrm{PW}$ were $75.5,78,80,77$ and 76, respectively. This result shows that addition of Parthenium weed to Goat manure will increase the moisture content of the slurry in the digester. 


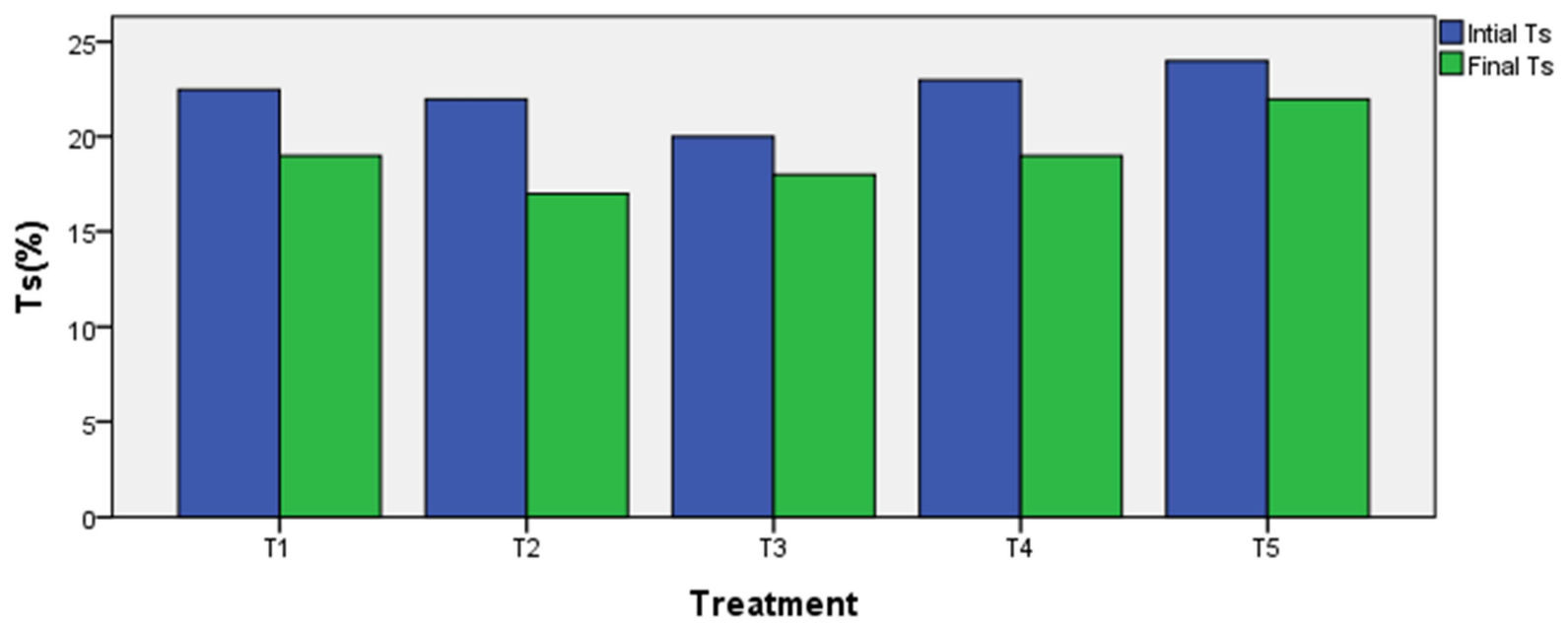

Figure 5. Values of TS for substrates before and after digestion.

Before AD, The maximum initial TS was measured in $100 \%$ Parthenium weed, whereas the minimum initial TS was registered in the digester which contains more Goat manure (Figure 3). this implies that Parthenium weed contains more biodegradable organic matter for biogas production and is a potential for suitable substrate for biogas production. The total solid content of all mix before AD was between $20 \pm 0.00 \%$ (i.e., 2 gram of TS from 10 gram sample) and $24 \pm 0.01 \%$.

Table 3. Values of VS for substrates before and after anaerobic digestion.

\begin{tabular}{llll}
\hline Treatments & Initial VS & Final VS & \%Volatile solid reduction \\
\hline D1 & 15.5 & 14 & 9.6 \\
D2 & 16 & 13 & 18.7 \\
D3 & 17 & 14 & 17.6 \\
D4 & 18 & 15 & 16.6 \\
D5 & 20 & 18 & 10 \\
\hline
\end{tabular}

The total solids and volatile solids were determined for all substrates both before and after AD.

\subsection{PH Values of the Digester}

$\mathrm{pH}$ is one of the indication factors of inhibition in anaerobic reactors. Therefore, the $\mathrm{pH}$ of each digester's substrate was recorded in two days interval on a regular basis.

Table 4 PH of each digester before and after $A D$.

\begin{tabular}{lll}
\hline Digester & Initial PH & Final PH \\
\hline $100 \% \mathrm{GM}$ & 6.97 & 7.29 \\
$75 \% \mathrm{GM}$ and $25 \% \mathrm{PW}$ & 6.92 & 7.78 \\
$50 \% \mathrm{GM}$ and $50 \% \mathrm{PW}$ & 6.91 & 7.93 \\
$25 \% \mathrm{GM}$ and $75 \% \mathrm{PW}$ & 6.81 & 8.08 \\
$100 \% \mathrm{PW}$ & 6.75 & 8.47 \\
\hline
\end{tabular}

The initial $\mathrm{pH}$ of each input mixture in digester was 6.97, $6.92,6.91,6.81$ and 6.75 . for the digester labeled as T1, T2, T3, T4 and T5 respectively. The PH of $100 \% \mathrm{GM}$ slurry before anaerobic digestion was about 6.97 , where as that of $100 \% \mathrm{PW}$ was 6.75 . as the amount of plant material added increases, $\mathrm{PH}$ starts to decrease. This shows goat manure helps to maintain the $\mathrm{PH}$ to meet the optimum required.
In anaerobic digestion, the optimum condition of acidity for biogas production is in the range 6.8 to 8.2. Biogas production rate will decline at $\mathrm{pH}$ condition higher or lower than the range [17].

It is generally agreed that at the initial stages of the overall process of biogas production, acid forming bacteria produce volatile fatty acids (VFA) resulting in declining $\mathrm{pH}$ and diminishing growth of methanogenic bacteria. That is, a low $\mathrm{pH}$ value inactivated microorganisms responsible for biogas production. In this regard, the $\mathrm{pH}$ of all the digesters was not in the range of optimal level 6.7 to 7.4 suitable for most methanogenic bacteria to function for biogas production as described by [18].

Increase in $\mathrm{PH}$ value of the substrates after anaerobic digestion may be attributed to production of alkali compounds, such as ammonium ions during the digestion of organic compounds in the digester [19].

Carbohydrate-rich substrates were good producers of VFAs and protein-rich substrates were good buffering capacity due to production of ammonia. So, if ratio between carbohydrate $(\mathrm{C})$ and protein $(\mathrm{N})$ are appropriate, biogas will be produced optimally [20].

\section{Conclusions and Recommendations}

\subsection{Summary and Conclusions}

In this study, out of the five treatments the optimum gas production was obtained in the 75 GM: $25 \%$ PW ratio which clearly indicates that parthenium hysterophorus as a substrate can be used as good supplement with goat manure and can be recommended that $75: 25 \%$ ratio should effectively be tried at commercial scale productions. It is concluded that, the production of biogas form 100\% GM, 75\%GM: 25\% PW, 50\% GM: 50\% PW, 25\% GM: 75\% PW and 100\%PW75\% were statistically significant at 0.05 significance level.

The use of co-substrate in anaerobic digestion systems improves biogas yield by positive synergies established in the digestion by increasing the availability of nutrients for the bacteria. co digestion of more than one substrate increases 
bacterial diversities that could provide buffering capacity that will enable for adjusting $\mathrm{PH}$ value to the optimum.

The co digestion of goat manure and parthenium weed not only resolves waste management, but also overcomes $\mathrm{C} / \mathrm{N}$ ratio imbalances in single digestion substrates and enhances the AD process.

The initial Volatile solid content of parthenium weed was $83.3 \%$ of the initial Total solid. This clearly shows that a large fraction of parthenium weed is biodegradable. so it is possible to conclude that $\mathrm{PW}$ is an important feed stock for biogas production.

\subsection{Recommendation}

Efforts should be made to measure the methane quality of the different combinations by a Gas Chromatography. Checking for toxic gases like hydrogen sulphide and ammonia with gas detection equipment should be carried out before entering an empty digester.

Government agencies should take an active part in biogas project in Ethiopia as it is done in other countries like India, Nepal, and philipinne e.t.c.

The result has indicated that co-digestion of GM and PW is more productive with $\mathrm{PW}$ proportion not exceeding $25 \%$. hence, further investigation will be beneficial for the future.

\section{Acknowledgements}

First and for most, I would like to praise my Heavenly Father God for His provision and courage throughout the course of my study. Next, I wish to express my sincere appreciation to my very understanding and helpful advisor, Dr. Meseret Chimdesa. It was only with their guidance and encouragement that the realization of the thesis was made possible. My deepest gratitude also goes to all my family members for their consistent material and moral support have been with me from the beginning to the end of my study.

\section{References}

[1] Confalonieri U, Menne B, Akhtar R, Ebi L, Hauengue M, Kovats R, Revich B and Woodward, 2007. Human health. Climate Change. Impacts, Adaptation and Vulnerability. Contribution of Working Group II to the Fourth Assessment Report of the Intergovernmental Panel on Climate Change

[2] Karve AD 2005. Compact biogas plant-compact, low-cost digester for biogas from waste starch. http://www.bioenergylists.org/en/ compact biogas accessed: $10^{\text {th }}$ Feb. 2009.

[3] Rao PV, Baral SS, Dey R, Mutnuri S. 2010. Biogas generation potential by anaerobic digestion for sustainable energy development in India. Renew. Sustain. Energy Rev., 14: 20862094.

[4] Vasudeo G (2005). Biogas Manure (BgM): a viable input in sustainable agriculture an integrated approach. International
Seminar on Biogas Technology for Poverty Reduction and Sustainable Development, Beijing, China.

[5] Tarisse A (2008). Natural gas consumption of Turkey and the strategic use of drought tolerant energy crops for biogas production. ESE-IERLyon III University.

[6] Tesfaye Nigussie. 2007. study on anaerobic digestion of Chat wastes. MSc. Thesis, Addis Ababa University, AdisAbaba, Ethiopia.

[7] El-Mashad HM, Zhang R, 2010. Biogas production from codigestion of dairy manure and food waste. BioresourTechnol 101: 4021-4028.

[8] Tchobanoglous, G., Theisen, H. and Vigil, S. 1993. Integrated Solid Waste Management Engineering Principle and Management Issues, 2nd, McGraw-Hill ISBN-10: 0070632375 pp: 978.

[9] Knottier, M. 2003. Integration of biomass technology, organic farming and energy crops. The future of biogas in Europe 11, European biogas workshop. Denmark.

[10] Thy, T. R. Preston and J. Ly, -Effect of retention time on gas production and fertilizer value of bio digester effluentll, Livest Res Rural Dev, Vol. 15, pp. 1-24, 2003

[11] Macias Corrral, M., Samani, Z., Hanson, A., Smith, G., Funk, P., Yu. 2008. Anaerobic digestion of municipal solid waste and agricultural waste and the effect of codigestion with dairy cow dung. Bioresource technology 99: 8288-8293.

[12] Nopharatana A., Pullammanappallil P. C. and Clarke W. P. 2007. Kinetic and dynamic modelling of batch anaerobic digestion of municipal solid waste in a stirred reactor. Waste management. 27: 595-603.

[13] Li R., Chen S. and Li X. 2009. Anaerobic codigestion of kitchen waste and cattle manure for methane production. Energy sources. 31: 1848-1856.

[14] Yadvika, Santosh, Sreekrishnan, T. R., Kohli, s. and Rana. 2004. Enhancement of biogas production from solid substrates using different technique: bio resource technology.

[15] Ahn, H., Smith, M., Kondrad, S. and White, J. 2009. Evaluation of biogas production potential by dry anaerobic digestion of switch grass-animal manure mixtures. Appl. Biochem. Biotechnology., 160: 965-975

[16] Eze J. I.; Agbo K. E. 2010. Studies on the microbial spectrum in anaerobic biomethanization of cow dung in $10 \mathrm{~m}^{3}$ fixed dome digester. Int. J. Physical Sci. 5, 1331-1337.

[17] Haug RT. 1993. The practical handbook of compost engineering. Florida: Lewis Publisher, 717 pp.

[18] Speece, 1996. R. E., "Anaerobic technology for industrial waste waters"USA, Archae Press. Verma, S. 2002. Anaerobic digestion of biodegradable organics in municipal solid.

[19] Verma, S. 2002. Anaerobic digestion of biodegradable organics in municipal solid.

[20] Gerardi, M. H., 2003. The microbiology of anaerobic digesters. Canada: John Wiley \& Sons, Inc. Gunaseelan VN. Impact of anaerobic digestion of inhibition potential of Parthenium soids. Biomass Bioenergy. 1998; 14: 179-184. 